\title{
Dendrobium 'Brazilian Fire 101' - New option of color of flowers for the orchid market
}

Jean C Cardoso

Vliet Flora, Lab. Biotecnol. Vegetal, C. Postal 394, 13825-000 Holambra-SP; jeancardosoctv@gmail.com

\begin{abstract}
Establishment of germplasm banks of ornamental species, together with breeding programs is fundamental for the growth of competitive cultivars of flowers that are the same or better quality than those developed in other countries. Around 100 progenies from a crossing between the cultivars Dendrobium 'Tong Chai Gold' and Dendrobium 'Black Jack' were obtained, from 50 plants which were selected and grown in pots in greenhouse conditions to evaluate the blooming stage and to select the progenies. Selection of vigorous growing plants and without disease symptoms were made in the period of cultivation. Also, there were evaluated the growing characteristics, rooting, early blooming, as well as the color, number and size of flowers in the first and second blooming. Six progenies with superior characteristics were chosen, from which Dendrobium 'Brazilian Fire 101' was obtained. This cultivar shows fast growth, good rooting, early flowering and high quality flowers, with predominantly yellow color, showing the ribs, the center of flowers and lip with red color. The durability of the flowers was 4560 days after anthesis.
\end{abstract}

Keywords: Floriculture, breeding, progenies, quality.

\section{RESUMO}

Dendrobium 'Brazilian Fire 101' - Nova opção de coloração de flores para o mercado de orquídeas

O estabelecimento de bancos de germoplasma de espécies ornamentais, consorciado a programas de melhoramento genético é fundamental para a produção de cultivares de flores competitivas em meio àquelas desenvolvidas no exterior. Foram obtidas 100 progênies provenientes de um cruzamento entre as cultivares Dendrobium 'Tong Chai Gold' e Dendrobium 'Black Jack', das quais 50 foram selecionadas e cultivadas em vaso e condições de estufa até o momento da floração e seleção de progênies. As seleções de plantas com crescimento vigoroso e sem sintomas de doenças foram realizadas ao longo do tempo de cultivo. Nessas, também foram avaliadas as características de crescimento, enraizamento, floração precoce, além de coloração, número e tamanho de flores na primeira e segunda floração. Foram escolhidas seis progênies com características superiores, das quais se obteve Dendrobium 'Brazilian Fire 101', que mostrou crescimento rápido, bom enraizamento, primeira floração de alta qualidade e flores com coloração predominantemente amarelo, com as nervuras, o centro e labelo vermelhos. A durabilidade das flores foi de 45-60 dias após a antese.

Palavras-chave: Floricultura, melhoramento, progênies, qualidade.

(Recebido para publicação em 14 de setembro de 2011; aceito em 24 de maio de 2012)

(Received on September 14, 2011; accepted on may 24, 2012)

$\mathrm{O}$ rchidaceae family includes more than 25,000 species, among which the Dendrobium genus is one of the most numerous with over 1,200 species, mostly originating from tropical and subtropical Asia and northern Australia (Wang et al., 2009). It was estimated that since the XVIII century over 8,000 new cultivars and hybrids of the Dendrobium genus have been produced in order to incorporate new color options for ornamental plants (Lavarack et al., 2006).

Thailand is a country of reference in the cultivation and development of Dendrobium cultivars and hybrids, seems to have started the commercial cultivation of orchids in 1934 with the development of the Dendrobium
'Pompadour'. This cultivar showed commercial interest, mainly because of its easy cultivation and propagation (Thammasiri, 2011).

The commercial cultivation of Dendrobium is relatively recent in Brazil and there is little information regarding the introduction of this species and commercial cultivation in the country. However, in fact, it is probably that this process is linked with the onset and development of studies in plant tissue culture laboratories, which allowed the mass propagation of cultivars imported from Asian countries, hitherto placed in private collections and with limited spread.

Although there are a large number of morphological variations in
Dendrobium, the marketable groups of this genus are two, the Nobile group (Dendrobium nobile), which produces inflorescences and flowers distributed along the pseudobulbs, and the Denphale group, that consists of hybrids from different species of the Dendrobium genus in the most, differentiated from the previous because the production of one or two terminal inflorescences in the pseudobulbs. Currently, a program of genetic improvement of Dendrobium nobile has obtained superior cultivars in relation to growing conditions in Brazil (Faria et al., 2009).

The breeding program of Dendrobium in Brazil has as its goal the production of cultivars with ornamental characteristics appropriate for the 
internal and external market, associated with the incorporation of agronomic traits such as resistance to pests and diseases, rapid growth and good flowering quality, economic viability and increasing the competitiveness of the culture compared with other species of ornamental importance, such as the Phalaenopsis orchid and Dendrobium cultivars and hybrids developed and imported from other countries.

The aim of this study was to obtain a denphale cultivar with agronomic characteristics that provide good yield and interesting ornamental characteristics to the market, through the recurrent selection of progeny from a cross between Dendrobium 'Tong Chai Gold' and 'Black Jack' cultivars.

\section{METHOD USED FOR BREEDING}

The breeding program of denphales has been developed in association with the Vliet Flora Company in the municipality of Holambra, São Paulo state, Brazil, and was started in 2007.

Controlled crosses were done between superior cultivars followed by several phenotypic selections during the development of the progeny, as described by Cardoso (2010). The two parental cultivars were Dendrobium 'Thong Chai Gold' ( + ) and Dendrobium 'Black Jack' (ठ઼).

Dendrobium 'Thonchai Gold' is a hybrid imported from Asia, with an average height of $30 \mathrm{~cm}$, a long inflorescence with 10-20 flowers of average size and yellow lemon colored sepals and petals, with a red lip (Figure 1). The petals and sepals have a similar diameter and are flat. It has rapid growth, good rooting in coconut chips, containing three to four erect pseudobulbs at the time of commercial flowering ( $2^{\text {nd }}$ flowering), which occurs about 18-24 months after the cultivation in the greenhouse. Flowering occurs predominantly in March and the durability of the flowers is 30-45 days. In Brazil, this cultivar shows problems with the abortion and blossom drop, and presents susceptibility to dry rot, an important disease in the culture, caused by Fusarium.
Dendrobium 'Black Jack' is also a hybrid imported from Asia, with medium to tall height, ranging from 30 to $50 \mathrm{~cm}$ at the time of commercial flowering ( $2^{\text {nd }}$ flowering), and a long inflorescence $(30-40 \mathrm{~cm})$ with 10-20 flowers of average size with deep red color. The petals and sepals show similar diameters and are curved moderately (Figure 1). It also has rapid growth, good rooting in coconut chips, containing three to four erect pseudobulbs at the time of flowering, which occurs about 12-24 months after cultivation in the greenhouse. The plants present no problems with abortion of flowers and blossom drop, but are susceptible to Fusarium dry rot disease. The durability of the flowers is around 60 days after anthesis.

Seeds were collected from fruits at the time of dehiscence, approximately 120 days after pollination, and were prepared and set to in vitro germination in culture medium described by Murashige \& Skoog (1962) with the salts reduced by half and the addition of $20 \mathrm{~g} \mathrm{~L}^{-1}$ of sucrose and $6.0 \mathrm{~g} \mathrm{~L}^{-1}$ of agar. The $\mathrm{pH}$ of the culture medium used for germination was 5.70.

The first in vitro selection occurred about 120 days after the cultivation of seeds, when about 100 different seedlings with small pseudobulb and starting development of leaves were chosen to the next phase of selection. Plants in stage of protocorms were discarded. Selected seedlings were cultivated in vitro for over 120 days, and soon after, acclimatized in a greenhouse with $70 \%$ shading, and temperature of $25 \pm 8^{\circ} \mathrm{C}, 80 \%$ relative humidity, in plastic trays of 150 cells with coconut fiber as substrate for more 120 days. Soon after this process, when the plants were ready for transplanting to final pot, the first in vivo selection was made, when approximately 50 plants, with at least two pseudobulbs and $10 \mathrm{~cm}$ in height, and with vigorous growth and without pest and disease symptoms were selected for the next phase. The chosen plants were transferred and planted in red plastic pots number $15(15 \mathrm{~cm}$ in diameter, $12.2 \mathrm{~cm}$ in height and with a 1.4 L capacity). Thereafter, the plants were transferred to the greenhouse with $60 \%$ shading, and temperature of $23 \pm 12^{\circ} \mathrm{C}$ and a variable relative humidity throughout the year (20-94\%).

The plants were cultivated using coconut chips as substrate, widely used in orchid cultivation for its durability, drainage and gas exchange capacity in relation to coconut fiber. Irrigation was performed using micro-sprinklers, applying approximately $2 \mathrm{~mm}$ of water, twice per week. Drip irrigation was performed using 20-20-20 ultra-soluble fertilizer plus $0.25 \%$ of $\mathrm{Ca}, 0.10 \%$ of $\mathrm{Mg}$ and $\mathrm{SO}_{4}^{-2}, 0.05 \%$ of Fe-chelate, $0.0125 \%$ of B and Cu-chelate, $0.025 \%$ of $\mathrm{Mn}$ and $\mathrm{Zn}$-chelate and $0.005 \%$ of Mo.

The final selections of the progenies were made during the first and second flowerings and were choose by horticultural and ornamental characteristics. The plants in the flowering stage were chosen according to the rapid and vigorous growth, well rooted, with no signs of pests and diseases, as well as by the number, shape and color of its flowers.

\section{MORPHOLOGICAL CHARACTERISTICS}

In the first flowering, about 12 months after cultivation in final pots (number 15), six plants with satisfactory vegetative and reproductive horticultural characteristics were selected with the purpose of the last stage of the breeding. In the second flowering, the Dendrobium 'Brazilian Fire 101' was selected as a new cultivar, because of its superior horticultural and ornamental characteristics compared to the others five previous selected.

Among the vegetative characteristics of this cultivar are: medium to tall size, three to four pseudobulbs with vertical growth, between 30 and 40 $\mathrm{cm}$ of height at the time of flowering, with few and compact leaves (Table 1). These characteristics are essential to increase the density of plants and to optimize the space use in the greenhouse cultivation. The use of number 15 plastic pots $(15 \mathrm{~cm}$ in diameter) permitted to to obtain a plant density of 30 plants/ $\mathrm{m}^{2}$ (high density) for this cultivar. The cultivar showed good rooting in 
Table 1. Vegetative morphological characteristics of Dendrobium 'Brazilian Fire 101' (características morfológicas vegetativas de Dendrobium 'Brazilian Fire 101'). Holambra, Vliet Flora, 2011.

\begin{tabular}{lcccc}
\hline & Pseudobulbs $\left(\mathbf{n}^{\mathbf{0}}\right)$ & Leaves $\left(\mathbf{n}^{\mathbf{0}}\right)$ & Height of plants $(\mathbf{c m})$ & Leaves $(\mathbf{L x W})$ \\
\hline First blooming & 3 & 9 & 30 & $18 \times 5.3$ \\
Second blooming & 4 & 15 & 40 & $14 \times 5.0$ \\
\hline
\end{tabular}

$\mathrm{L}=$ Length (comprimento), $\mathrm{W}=$ Width (largura).

Table 2. Reproductive morphological characteristics of Dendrobium 'Brazilian Fire 101' (características morfológicas reprodutivas de Dendrobium 'Brazilian Fire 101'). Holambra, Vliet Flora, 2011.

\begin{tabular}{|c|c|c|c|c|c|c|}
\hline & \multirow{2}{*}{$\mathbf{N}^{\circ}$ Infloresc } & \multirow{2}{*}{$\mathbf{N}^{\circ}$ Flowers } & \multicolumn{4}{|c|}{ Diameters (horizontal $x$ vertical) $(\mathrm{cm})$} \\
\hline & & & Flowers & Petals & Lips & Sepals \\
\hline $1^{\text {st }}$ Flowering & 1 & 14 & $8.12 \times 6.60$ & $4.33 \times 2.52$ & $3.16 \times 1.67$ & $3.58 \times 1.62$ \\
\hline $2^{\text {nd }}$ Flowering & 1 & 18 & $8.17 \times 6.63$ & $4.37 \times 2.53$ & $3.17 \times 1.67$ & $3.60 \times 1.63$ \\
\hline
\end{tabular}

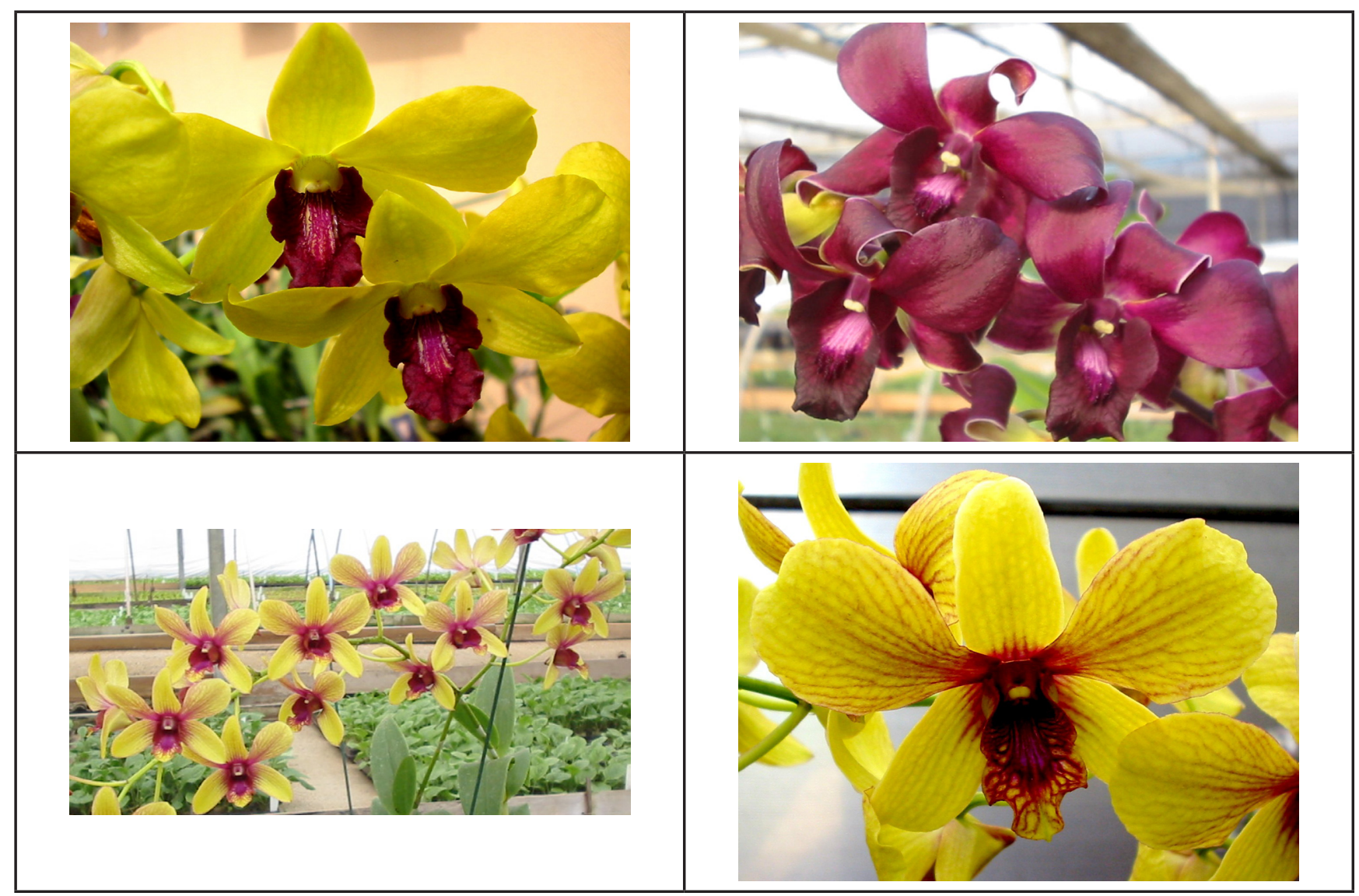

Figure 1. Flowering characteristics of the selected progenie Dendrobium 'Brazilian Fire 101' (photos below) and female (Dendrobium 'Tong Chai Gold'; left and above photo) and male (Dendrobium 'Black Jack', right and above photo) parents (características do florescimento da progênie selecionada Dendrobium 'Brazilian Fire 101' e dos genitores feminino (Dendrobium 'Tongchai Gold', foto superior esquerda) e masculino (Dendrobium 'Black Jack', foto superior direita). Holambra, Vliet Flora, 2011.

coconut chips. Because of the good rooting and growing up and right, this selected cultivar does not need staking in the vegetative phase, reducing human labor costs.

During the 18 months of cultivation no symptoms of pests and diseases were observed on leaves, flowers and pseudobulbs of the Dendrobium 'Brazilian Fire 101'. Also, this cultivar seems to be tolerant to Botrytis, a disease that cause brown spots in the orchid flowers, reduces its quality, even in the presence of other cultivars showing these symptoms, as Dendrobium 'Tong Chai Gold', for example.
About the reproductive characteristics, the Dendrobium 'Brazilian Fire 101' cultivar showed flowering within a similar period as other cultivars (18 months of greenhouse cultivation). The first flowering, which occurred in August 2010, showed satisfactory commercial quality, with 
inflorescence between 40-45 $\mathrm{cm}$ and 14 flowers with good quality and average size (Table 2). The use of first flowering with commercial intent represents an important goal in breeding programs, beyond the development of new Dendrobium cultivars because, most often the first flowering is poor and with few flowers, increasing the time of greenhouse cultivation and delaying its commercialization.

The flowers of Dendrobium 'Brazilian Fire 101' showed colors varying from yellow to deep red (Figure 1). The dorsal and lateral sepals showed intense yellow coloration, with the proximal region with red color. The lateral petals showed variable color from yellow to red. In the proximal region of the petal (center of flower) the red color predominates, and in the distal region the yellow is the predominant color. The color staining of the red / yellow decrease / increase from the proximal to the distal region of flowers. In the middle of the petals can be observed a yellow color with red streaks. The same occurs with the lip, but in a greater intensity and proportion of red, showing only the distal region with yellow color. The column has an intense red color with the pollinia cap white-colored.

The second flowering occurred between December and January, a period when flower demand is high and the flowered orchids availability decreases. The cultivar Dendrobium 'Brazilian Fire 101 ' might be an alternative to offseason production, when there is a lack of flowering orchids and supply prices of marketing rise. Also, this cultivar flowers two to three times a year with flores of high durability (45 to 60 days).

The staking and preparation of the plant at the induction and development of inflorescence moment is recommended to prevent inflorescence breakage at the time of handling, transport and sale, due to the long inflorescence and great number of flowers of this cultivar.

The use of controlled crosses between orchid cultivars with well defined characteristics, followed by recurrent selection of the progenies in in vitro growth and in greenhouse conditions, during all the culture period, has been used successfully in obtaining superior cultivars of the orchid genus Dendrobium, such as seen in this work, and in other orchids genus, such as Laeliocattleya (Cardoso, 2010). Among the advantages of this technique is the small number of progenies required in the selection phase, which reduces the area of cultivation and the production costs, allowing to use fewer plants obtained from crossing in the selection of new cultivars.

Currently, the high and increasing demand for high quality flowers in the whole country (Veilling, 2011) has required technological innovations both for the development of new products/ cultivars as well as the reduction of production costs. In this context, obtaining new colors or combinations for the market of ornamental plants is a key feature for the success of growing, both in cultivation as well as the product acceptance by the final consumer. Phalaenopsis orchids are an example and present great variability in horticultural and ornamental characteristics among cultivars. Phalaenopsis is one of the main potted flowers sold in most markets (Chone \& Oliveira, 2005) and is the first potted flower, in quantity, sold in Veilling-Holambra (Veilling 2011), explained in part because of the great variety of colors available from different abroad breeding companies, high quality and durability of its flowers that can compete in relation to the marketing of other orchids, such as Dendrobium.

In this context, and associated with the increasing of the flowers market in Brazil, the obtaining of new Dendrobium cultivars developed and selected in local climate conditions of Brazil, as done in this work, resulted in a cultivar with high horticultural and ornamental qualities, and with flowers that showed different colors. This is one of the first steps to obtain a competitive product in relation to the Phalaenospis and others orchid cultivars developed abroad. Also, Dendrobium 'Brazilian Fire 101 ' can be used off-season on potted flowers market.

\section{MAINTENANCE AND DISTRIBUTION OF PLANTS}

The cultivar is being maintained, micropropagated and marketed in the Laboratory of Plant Biotechnology of the Vliet Flora Company, located in Holambra-SP.

\section{ACKNOWLEDGEMENTS}

Thanks to the Vliet Flora Company for finantial support and credibility to this breeding program for orchids.

\section{REFERENCES}

CARDOSO JC. 2010. Laeliocattleya 'Brazilian Girl Rosa': cultivar de orquídea para cultivo em vaso. Horticultura Brasileira 28: 378-381.

CHONE RMS; OLIVEIRA LH. 2005 Desenho e análise da cadeia produtiva de plantas ornamentais: $\mathrm{O}$ caso das orquídeas do gênero Phalaenopsis. In: International meeting of the iberoamerican academy of management, 4. Annals..., Lisboa. Disponível em www. administradores.com.br/...phalaenopsis/.../ download/. Acessado em 27 de Outubro de 2011.

DE FARIA RT; TAKAHASHI LSA; LONE AB. 2009. UEL 6: nova cultivar de Dendrobium. Horticultura Brasileira 27: 114-115.

LAVARACK B; LAVARACK PS; HARRIS W; STOCKER G. 2006. Dendrobium and its Relatives. Portland: Timber Press, 287p.

MURASHIGE T; SKOOG F. 1962. A revised medium for rapid growth and bio assays with tobacco tissue cultures. Physiologia Plantarum 15: 473-497.

THAMMASIRI K. 4 de Maio de 2011. Thai orchid production for the world market. Available in: http://www.delfinadearaujo. com/on/specialWOC/entrevistas/thammasiri/ thammasiriport.htm.

VEILLING. 27 de Outubro de 2011. Velling News 2010. Available at: http://www.veiling. com.br/.

WANG HZ; FENG SG; LU JJ; SHI NN; LIU JJ. 2009. Phylogenetic study and molecular identification of 31 Dendrobium species using inter-simple sequence repeat (ISSR) markers. Scientia Horticulturae 122: 440-447. 